UDC 544.473-039.63

\title{
CONVERSION OF ETHANOL OVER BINARY COPPER CONTAINING CATALYSTS
}

\author{
S.H. Mammadova, K.Kh. Aghayeva \\ Azerbaijan State Oil and Industry University, \\ Azadlig 20, Baku, AZ-1010, Azerbaijan, e-mail: salimaabbaszade@mail.ru
}

Received 05.01.2020

Accepted 07.04.2020

\begin{abstract}
The reaction of ethanol conversion over binary copper-cerium and copper-tungsten oxide catalysts was studied. It found that the activity of examined samples depends both on temperature reactions and their composition. It revealed that on examined copper containing catalysts, the dependences of acetic aldehyde and acetone yields on the composition of the catalyst have the form of curves with two maxima which is apparently due to changes in the phase composition of binary copper containing catalysts. It established that in the reaction of ethanol conversion over cerium copper oxide catalysts the formation of ethyl acetate proceeds on weakly crystalline samples, and the formation of acetaldehyde on medium crystalline samples. It indicated that increase in the degree of crystallinity of binary copper-tungsten oxide catalysts leads to increase in the yields of ethanol partial oxidation products and to decrease in the yield of carbon dioxide.
\end{abstract} Keywords: ethanol conversion, binary catalysts, copper oxide, acetic aldehyde, acetone.

DOI: 10.32737/2221-8688-2020-2-199-206

\section{Introduction}

As it is known, one of the important areas of bioethanol use is its conversion into various monomers much-needed for the chemical industry. By means of the reaction of ethanol conversion, compounds such as ethylene, diethyl ether, aldehyde, ethyl acetate, acetone and acetic acid can be obtained [1-3]. The value of using ethanol as a feedstock for the production of these compounds is due to the fact that ethanol is a renewable raw material as it is obtained in large quantities from plant materials. Reactions of ethanol conversion are of both scientific and great practical interest due to the fact that the reaction products are widely used in the chemical and petrochemical industries.

Catalysts based on metals such as copper, cerium, etc. are used to carry out these reactions [4-6]. At the same time, surface and structural properties of the catalysts, such as crystallinity, surface area, phase composition, etc., affect their activity [7-10]. In this regard, the paper explored the reaction of ethanol conversion over binary cerium-copper and tungsten-copper oxide catalysts, as well as the effect of the degree of crystallinity on their activity.

\section{Experimental part}

Binary cerium-copper oxide catalysts of various compositions were prepared by coprecipitation from aqueous solutions of cerium and copper nitrate salts. Binary tungstencopper oxide catalysts of various compositions were prepared by coprecipitation from aqueous solutions of ammonium tungstate and copper nitrate. The obtained mixtures were successively evaporated and dried at 100$120^{\circ} \mathrm{C}$, decomposed at $250^{\circ} \mathrm{C}$ until nitrogen oxides were completely isolated, and then calcined at $600^{\circ} \mathrm{C}$ for ten hours. Thus, 9 catalysts with an atomic ratio of elements from $\mathrm{Ce}: \mathrm{Cu}=1: 9$ to $\mathrm{Ce}: \mathrm{Cu}=9: 1$ and 9 samples with an atomic ratio of elements from $\mathrm{W}: \mathrm{Cu}=1: 9$ to $\mathrm{W}: \mathrm{Cu}=9: 1$ were synthesized. The activity of the synthesized catalysts was studied on a flowthrough installation with a tubular reactor in the temperature range of $100-500^{\circ} \mathrm{C} .5 \mathrm{ml}$ of the 
examined catalyst with a grain size of 1.0-2.0 $\mathrm{mm}$ was loaded into the reactor,

and its activity in the ethanol conversion reaction was studied. A mixture of ethanol with steam and nitrogen with an ethanol: water: nitrogen ratio of 1: 4: 5 was passed through the catalyst loaded into the reactor. The space velocity of the feed mixture was $1200 \mathrm{~h}^{-1}$. Carbon dioxide was determined on a chromatograph with a thermal conductivity detector and a 3-meter-long column filled with liquid paraffin deposited on INZ brick. Ethanol and its conversion products were determined on a chromatograph with a flame ionization detector on a $3 \mathrm{~m}$ long column filled with specially treated Polysorb-1 sorbent. X-ray analysis of binary cerium-copper and tungstencopper oxide catalysts was carried out on a Bruker automatic D2 Phaser powder diffractometer $(\mathrm{CuK} \alpha$ radiation, $\mathrm{Ni}$ filter, $3 \leq 2 \theta \geq 80^{\circ}$ ).

\section{Results and discussion}

The results of X-ray diffraction studies showed that in the $\mathrm{Cu}-\mathrm{W}-\mathrm{O}$ catalyst system three phases were formed of the initial oxides of copper and tungsten, as well as copper tungstate. In all samples, the percentage ratio of the components was preserved, as evidenced by regular changes in the intensities of reflections in diffraction patterns. Investigations of the $\mathrm{Ce}-$
$\mathrm{Cu}-\mathrm{O}$ system showed that, except for $\mathrm{Ce}-$ $\mathrm{Cu}=1-9$ catalyst, $\mathrm{CeO}_{2}$ and $\mathrm{CuO}$ oxides were formed in all ratios samples. The X-ray patterns of the $\mathrm{Ce}-\mathrm{Cu}-1-9$ sample contained peaks responsible for phases of $\mathrm{CeO}_{2}$ and elemental copper. We also calculated the degree of crystallinity of the examined samples which are shown in Table 1.

Table 1. Degree of crystallinity of binary copper-tungsten and copper-cerium oxide catalysts of various compositions

\begin{tabular}{|l|l|l|l|l|l|l|l|l|l|}
\hline $\begin{array}{l}\text { Atomic ratio of copper to tungsten or } \\
\text { cerium }\end{array}$ & $1-9$ & $2-8$ & $3-7$ & $4-6$ & $5-5$ & $6-4$ & $7-3$ & $8-2$ & $9-1$ \\
\hline $\begin{array}{l}\text { Degree of crystallinity of the Cu-W-O } \\
\text { catalytic system, } \%\end{array}$ & 84.2 & 85.5 & 85.7 & 84.1 & 83.0 & 79.8 & 77.6 & 66.6 & 41.3 \\
\hline $\begin{array}{l}\text { Degree of crystallinity of the Cu-Ce-O } \\
\text { catalyst system, \% }\end{array}$ & 71.2 & 64.6 & 67.9 & 70.4 & 62.5 & 52.7 & 63.0 & 59.1 & 66.7 \\
\hline
\end{tabular}

As can be seen from Table 1, an increase of the copper content in the composition of the binary catalyst leads to a decrease in the degree of crystallinity.

Studies showed that the products of ethanol conversion over binary cerium-copper oxide catalysts are acetaldehyde, ethyl acetate, acetone, ethylene and carbon oxides. The temperature dependence of the activity of the catalyst $\mathrm{Ce}-\mathrm{Cu}=4-6$ in the ethanol conversion reaction is shown in Fig.1. It can be seen that the yields of acetaldehyde, acetone and ethyl acetate pass through a maximum as reaction temperature rises. Also, it can be seen from the figure that the yield of ethylene slightly increases with increasing reaction temperature, while the yield of carbon dioxide increases sharply and reaches $31.5 \%$ at $450^{\circ} \mathrm{C}$. The ethanol conversion, as can be seen from Figure 1 , increases with a reaction temperature to $73.8 \%$ at $450{ }^{\circ} \mathrm{C}$. The highest yield of acetone on this catalyst reaches $41.3 \%$ at $400^{\circ} \mathrm{C}$. Almost similar dependences were obtained for the remaining cerium-copper oxide catalysts. 


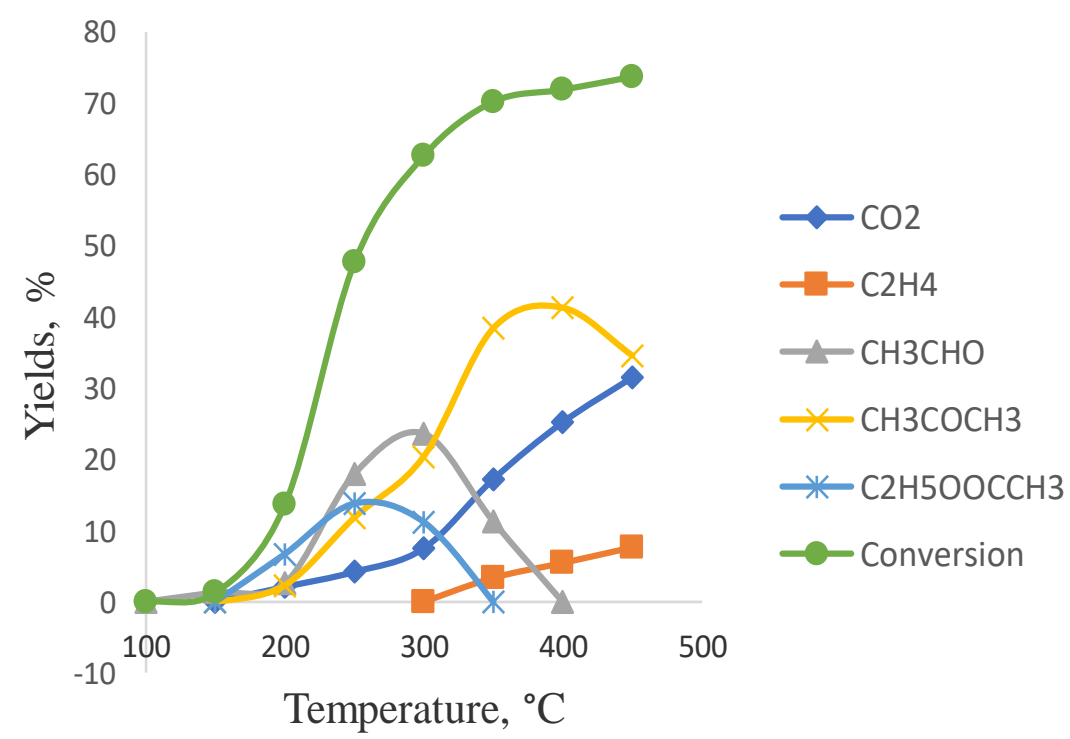

Fig. 1. Effect of temperature on the reaction products of ethanol dehydrogenation over a catalyst $\mathrm{Ce}-\mathrm{Cu}=4-6$.

Our studies showed that the atomic ratio of cerium to copper strongly affected the activity of cerium of copper oxide catalysts in the reaction of ethanol conversion. Table 2 shows the yields of ethanol conversion products on cerium copper oxide catalysts of various compositions at a temperature of $350^{\circ} \mathrm{C}$.

Table 2 shows that at a temperature of $450^{\circ} \mathrm{C}$, the yield of carbon dioxide with increased cerium content in the composition of the catalyst increased and on the catalyst $\mathrm{Ce}: \mathrm{Cu}=5: 5$ is $77 \%$. The formation of other reaction products was not practically observed on this catalyst. The dependence of ethylene yield on the atomic ratio of cerium to copper in the composition of the catalyst has the form of a curve with two maxima on the catalysts $\mathrm{Ce}: \mathrm{Cu}=4: 6$ and $\mathrm{Ce}: \mathrm{Cu}=6: 4$. Table 2 also shows that as cerium content in the composition of the catalyst rose the yield of acetic aldehyde decreased to $0 \%$ over the catalyst on samples with approximately the same ratio of cerium and copper, and then increased to $12.8 \%$ on the sample of $\mathrm{Ce}: \mathrm{Cu}=8: 2$ catalyst. The acetone yield with a change in the cerium content in the composition of the catalyst also has the form of a curve with two maxima on the catalysts $\mathrm{Ce}: \mathrm{Cu}=3: 7$ and $\mathrm{Ce}: \mathrm{Cu}=6: 4$. On these catalysts, the acetone yield reaches about $47 \%$. The formation of ethyl acetate is observed in several of the samples studied and does not exceed $10.5 \%$. As can be seen from table 2, the conversion of ethanol on the studied catalysts at $450^{\circ} \mathrm{C}$ varies from 68 to $92 \%$. Studies have shown that similar dependences the influence of the composition of the catalysts on their activity were obtained at other temperatures.

Table 2. Yields of reaction products of ethanol conversion over $\mathrm{Ce}-\mathrm{Cu}-\mathrm{O}$ catalytic system.

$$
\mathrm{T}=450^{\circ} \mathrm{C} \text {. }
$$

\begin{tabular}{|c|l|l|l|c|c|c|}
\hline \multirow{2}{*}{$\begin{array}{l}\text { Atomic ratio } \\
\text { cerium to copper }\end{array}$} & \multicolumn{5}{|c|}{ Yields of reaction products, \%. } & $\begin{array}{l}\text { Conversion, } \\
\%\end{array}$ \\
\cline { 2 - 7 } & $\mathrm{CO}_{2}$ & $\mathrm{C}_{2} \mathrm{H}_{4}$ & $\mathrm{CH}_{3} \mathrm{CHO}$ & $\mathrm{CH}_{3} \mathrm{COCH}_{3}$ & $\mathrm{C}_{2} \mathrm{H}_{5} \mathrm{OOCCH}_{3}$ & 80.6 \\
\hline $1: 9$ & 12.6 & 2.4 & 23.5 & 2.1 & 1 & 81 \\
\hline $2: 8$ & 35.2 & 2.4 & 14.5 & 18.4 & 10.5 & 91.6 \\
\hline $3: 7$ & 29.4 & 5.6 & 9,6 & 47 & 0 & 73.8 \\
\hline $4: 6$ & 31.5 & 7.7 & 0 & 34.6 & 0 & 77 \\
\hline $5: 5$ & 77 & 0 & 0 & 0 & 0 & \\
\hline
\end{tabular}




\begin{tabular}{|c|c|c|c|c|c|c|}
\hline $6: 4$ & 31.5 & 12.8 & 0 & 36.1 & 4.5 & 84.9 \\
\hline $7: 3$ & 30.9 & 10.8 & 1.8 & 22.7 & 3.2 & 68.4 \\
\hline $8: 2$ & 30.5 & 9.6 & 12.8 & 22.1 & 0 & 75 \\
\hline $9: 1$ & 30.6 & 12.5 & 5.1 & 22.1 & 0 & 70.3 \\
\hline
\end{tabular}

Thus, on the basis of the studies conducted it can be said that the main reaction products on cerium copper catalysts are acetic aldehyde, acetone, and ethyl acetate. The yield and distribution of reaction products on cerium copper catalysts depends on both the reaction temperature and the atomic ratio of cerium to copper.

A study of the activity of $\mathrm{Cu}-\mathrm{W}-\mathrm{O}$ catalysts showed that the reaction products of ethanol conversion on the examined catalytic system were acetic aldehyde, acetone, ethylene, and carbon dioxide. Studies showed that the yield and distribution of ethanol conversion products strongly depended both on the reaction temperature and the atomic ratio of copper to tungsten in the composition of the catalyst. As an example, the influence of the reaction temperature on the yields of ethanol conversion products on a $\mathrm{Cu}: \mathrm{W}=1: 9$ catalyst is shown in Fig. 2.

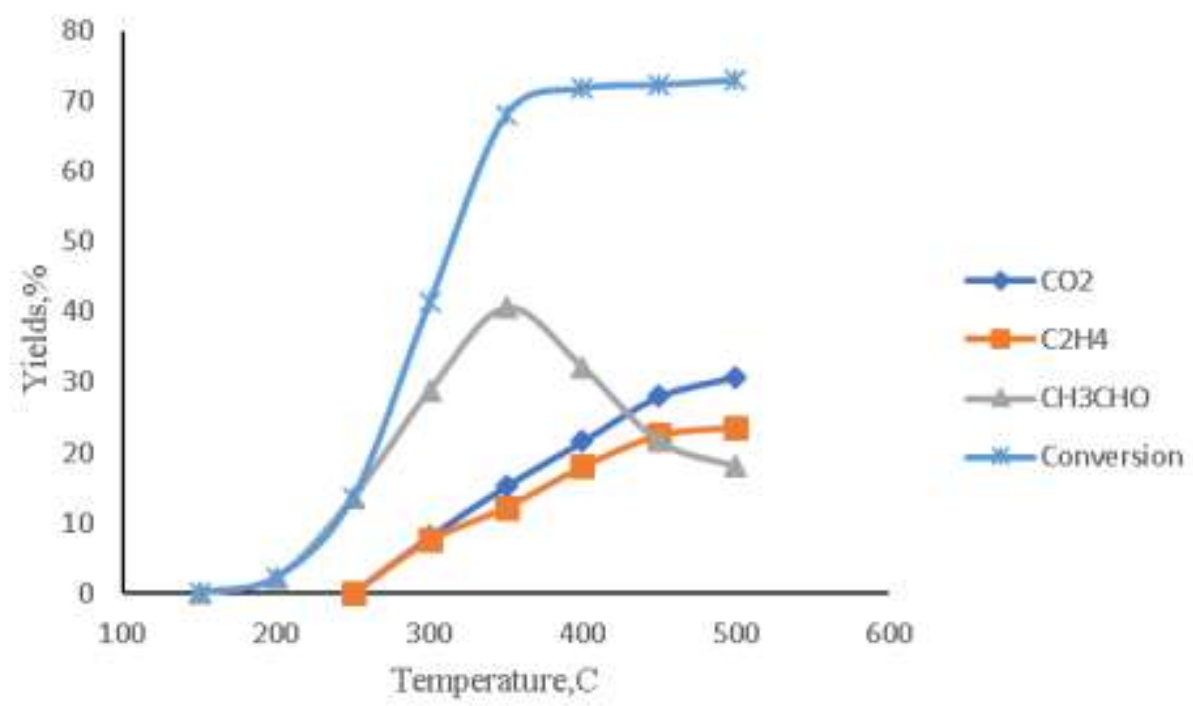

Fig. 2. Effect of temperature on the yields of reaction products of the ethanol conversion over catalyst $\mathrm{Cu}-\mathrm{W}=1-9$.

Figure 2 shows that the reaction of ethanol conversion on the studied catalyst begins at a temperature of $200^{\circ} \mathrm{C}$ with the formation of $2.2 \%$ acetic aldehyde and, with a further increase in the reaction temperature, passes through a maximum at $350^{\circ} \mathrm{C}$. A further increase in the reaction temperature leads to the formation of other reaction products as well. The yields of ethylene and carbon dioxide increase symbatically in the entire studied temperature range, reaching their maximum value at $500^{\circ} \mathrm{C}$. As can be seen from Figure 2 on the $\mathrm{Cu}: \mathrm{W}=1: 9$ catalyst, the conversion of ethanol reaches $73 \%$.

Table 3 shows the dependence of the yields of the reaction products of ethanol conversion at $450^{\circ} \mathrm{C}$ on the atomic ratio of copper to tungsten in the composition of $\mathrm{Cu}-\mathrm{W}$ $\mathrm{O}$ catalysts. It can be seen that with an increase of the copper content in the catalyst, the yield of acetic aldehyde passes through a maximum on the $\mathrm{Cu}-\mathrm{W}=3: 7$ samples $(52.4 \%)$ and then slowly decreases to $32.6 \%$ on the $\mathrm{Cu}-\mathrm{W}=9-1$ catalyst. The yield of ethylene with an increase of the copper content in the composition of the catalyst decreases and is practically equal zero on samples rich with copper. The yield of the product of ethanol deep oxidation carbon dioxide with an increase of the copper content in the composition of the catalyst is first slightly 
reduced, and then practically unchanged. As can be seen from table 3 , the dependence of the conversion of ethanol on the composition of the catalyst has the form of a curve with two peaks, and the highest conversion of ethanol reaches $90.8 \%$.

Table 3. Dependences of the yields of the reaction products of the ethanol conversion at $450^{\circ} \mathrm{C}$ on the atomic ratio of copper to tungsten in the catalyst composition.

\begin{tabular}{|l|l|l|l|l|l|l|l|l|l|}
\hline Reaction products & \multicolumn{9}{|l|}{ Yields, \% } \\
\hline Ratio of copper to tungsten & $1-9$ & $2-8$ & $3-7$ & $4-6$ & $5: 5$ & $6-4$ & $7-3$ & $8-2$ & $9-1$ \\
\hline Carbon dioxide & 21.6 & 19.7 & 16.8 & 17.8 & 20.4 & 19.8 & 23.2 & 20.3 & 24.6 \\
\hline Ethylene & 18 & 13 & 9.4 & 5.4 & 4.8 & 4.3 & 0 & 0 & 0 \\
\hline Acetic Aldehyde & 32.2 & 50.8 & 56.4 & 52.4 & 44.4 & 52.6 & 45.6 & 40.4 & 37.4 \\
\hline Acetone & 0 & 6 & 5.2 & 0 & 0 & 6.2 & 1.5 & 1.2 & 0 \\
\hline Ethanol conversion & 71.8 & 89.5 & 87.8 & 75.9 & 69.9 & 83 & 70.3 & 66.3 & 63.5 \\
\hline
\end{tabular}

The obtained results show that on the examined copper containing catalysts the dependences of the yields of acetic aldehyde and acetone on the catalyst composition have the form of curves with two maxima. Apparently, this is due to changes in both the phase composition of the catalysts and the formation of solid solutions on the samples with maximum yields of the target products. In this regard, we compared the activity of the studied catalysts with the degree of crystallinity. Fig. 3 shows dependences of the yields of acetaldehyde, ethyl acetate, acetone, and carbon dioxide in the reaction of ethanol conversion over cerium copper oxide catalysts on the degree of crystallinity of the samples.

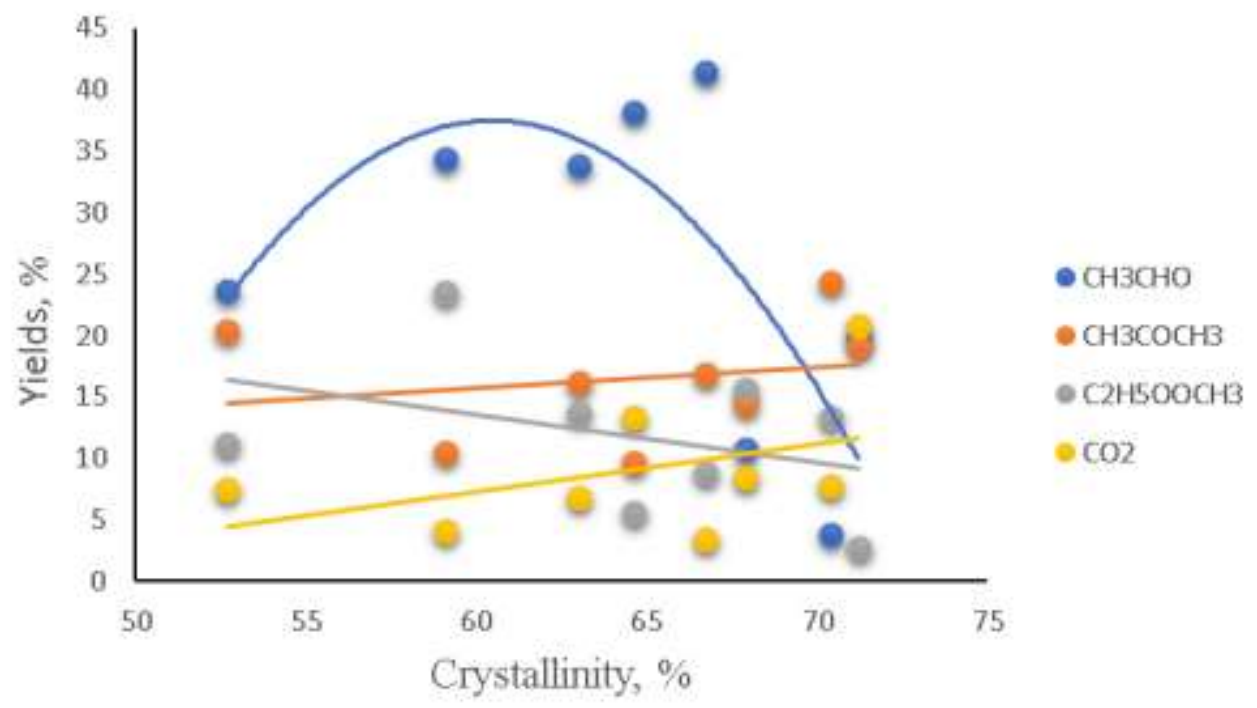

Fig. 3. Dependence of the yields of the reaction products of ethanol conversion on the degree of crystallinity of binary cerium-copper oxide catalysts.

As can be seen with increasing degree of crystallinity, the yield of ethyl acetate decreases, and the yield of acetaldehyde passes through a maximum These data allow us to assume that in the reaction of ethanol conversion over cerium copper oxide catalysts, the formation of ethyl acetate proceeds on weakly crystalline samples, and in the formation of acetaldehyde on medium crystalline samples. Figure 3 also shows that the yields of acetone and carbon dioxide increase with increasing crystallinity of the catalyst, i.e. they change symmetrically. Based on this, it can be assumed that acetone and carbon dioxide are 
products of the same reaction and their formation occurs at the same centers.

The dependence of the yields of the reaction products of ethanol conversion on the degree of crystallinity of binary copper-tungsten oxide catalysts is shown in Fig.4.

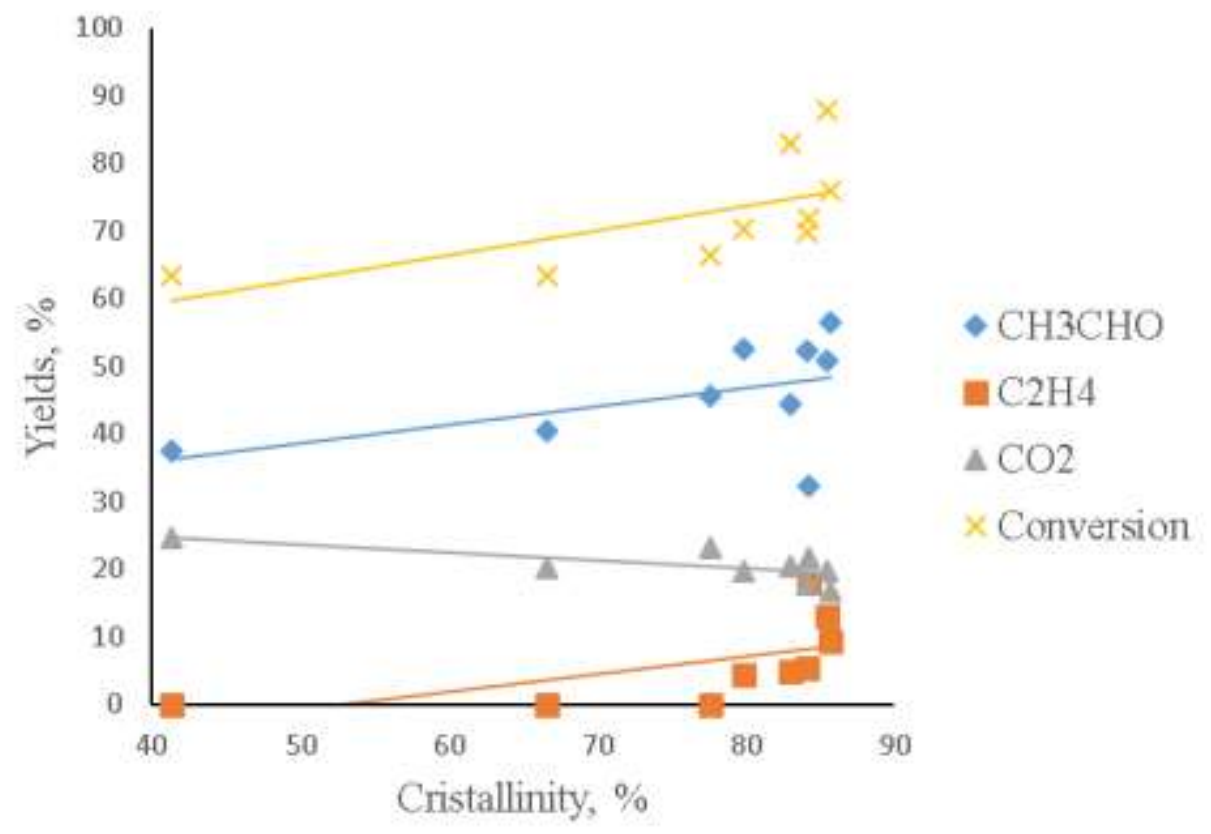

Fig.4. Dependence of the yields of reaction products of ethanol conversion on the degree of crystallinity of binary copper-tungsten oxide catalysts.

As can be seen from Figure 4, with an increase in the degree of crystallinity of the catalyst, the yields of acetic aldehyde and ethylene increase, while the yield of carbon dioxide decreases. Figure 1 also shows that the conversion of ethanol also increases with increasing degree of crystallinity of the catalyst.

\section{Conclusion}

1. Main products of ethanol conversion on binary cerium-copper and tungsten-copper oxide catalysts are acetaldehyde, acetone and ethyl acetate.

2. Over the examined copper-containing catalysts, the dependences of the yields of acetic aldehyde and acetone on the composition of the catalyst have the form of curves with two maxima.

3. Increase in the degree of crystallinity of binary copper-tungsten oxide catalysts leads to the increase in the yields of products of partial oxidation of ethanol and to the decrease in the yield of carbon dioxide.

4. In the reaction of ethanol conversion over the examined samples, acetone and carbon dioxide are the products of the same destructive decomposition of ethanol and their formation occurs at the same centers.

\section{References}

1. Sohta Akiyama, Akimitsu Miyaji, Yoshihiro Hayashi, Misao Hiza, Yasumasa Sekiguchi, Toru Koyama, Akinobu Shiga, Toshihide Baba, Selective conversion of ethanol to 1,3butadiene using germanium talc as catalyst. Journal of Catalysis. 2018, vol. 359, pp. 184-197.
2. Dongni Yu, Weili Dai, Guangjun Wu, Naijia Guan, Landong Li, Stabilizing copper species using zeolite for ethanol catalytic dehydrogenation to acetaldehyde. Chinese Journal of Catalysis. 2019, vol. 40, issue 9, pp. 1375-1384. 
3. Chaowa tAutthanit, Piyasan Praserthdam, Bunjerd Jongsomjit, Oxidative and nonoxidative dehydrogenation of ethanol to acetaldehyde over different VOx/SBA-15 catalysts. Journal of Environmental Chemical Engineering. 2018, vol. 6, issue 5, pp. 6516-6529.

4. Junjun Shan, Nare Janvelyan, Hang Li, Jilei Liu, Tobias M.Egle, Jianchao Ye, Monika M.Biener, Juergen Biener, Cynthia M.Friend, Maria Flytzani-Stephanopoulos. Selective non-oxidative dehydrogenation of ethanol to acetaldehyde and hydrogen on highly dilute $\mathrm{NiCu}$ alloys. Applied Catalysis B: Environmental. 2017, vol. 205, pp. 541-550.

5. Mamontov G.V., Grabchenko M.V., Soboleva V.I., Zaikovskii V.I., Vodyankina O.V. Ethanol dehydrogenation over Ag$\mathrm{CeO} 2 / \mathrm{SiO} 2$ catalyst: Role of $\mathrm{Ag}-\mathrm{CeO} 2$ interface. Applied Catalysis A: General. 2016, vol. 528, pp. 161-167.

6. Andrea Malmusi, Juliana Velasquez Ochoa, Tommaso Tabanelli, Francesco Basile, Carlo Lucarelli, Stefano Agnoli, Francesco Carraro, Gaetano Granozzi, Fabrizio Cavani. Ethanol aerobic and anaerobic oxidation with $\mathrm{FeVO} 4$ and V2O5 catalysts. Applied Catalysis A: General. 2019, vol. 570, pp. 139-147.

7. Shanlei Han, Tatiana Otroshchenko, Dan Zhao, Henrik Lund, Nils Rockstroh, Thanh
HuyenVuong, Jabor Rabeah, Uwe Rodemerck, David Linke, Manglai Gao, Guiyuan Jiang, Evgenii V.Kondratenko. The effect of $\mathrm{ZrO} 2$ crystallinity in $\mathrm{CrZrOx} / \mathrm{SiO} 2$ on non-oxidative propane dehydrogenation. Applied Catalysis A: General, 2020, vol. 590, p. 117350

8. Ming Zhao, Yanfang Wu, Weiwei Cai, Tian Xia, Wen-Jie Jiang, Wei Ding, Jing-Pei Cao. Boosting hydrogen evolution activity and durability of $\mathrm{Pd}-\mathrm{Ni}-\mathrm{P}$ nanocatalyst via crystalline degree and surface chemical state modulations. International Journal of Hydrogen Energy, 2019, vol. 44, issue 59, pp. 31053-31061.

9. Norman S.Allen, Noredine Mahdjoub, VladimirVishnyakov, Peter J.Kelly, Roelof J.Kriek. The effect of crystalline phase (anatase, brookite and rutile) and size on the photocatalytic activity of calcined polymorphic titanium dioxide (TiO2). Polymer Degradation and Stability, 2018, vol. 150, pp. 31-36.

10. Gihoon Lee, Ilho Kim, Inchan Yang, JeongMyeong Ha, Hyon Bin Na, Ji Chul Jung. Effects of the preparation method on the crystallinity and catalytic activity of LaAlO3 perovskites for oxidative coupling of methane. Applied Surface Science, 2018, vol. 429, pp. 55-61.

\title{
BİNAR MIS TORKIBLI KATALIZATORLAR ÜZORINNDO ETANOLUN CQEVRILLOSİ
}

\author{
S.H. Mommədova, K.X. Ăgayeva \\ Azarbaycan Dövlat Neft va Sanaye Universiteti \\ Azadlıq pr., 20,Baku,AZ-1010, e-mail: salimaabbaszade@mail.ru
}

Binar mis serium və mis volfram oksid katalizatorları üzərində etanolun çevrilmə reaksiyası tədqiq olunmuşdur. Göstərilmişdir ki, tədqiq olunan nümunolorin aktivliyi hom reaksiya temperaturundan, hamdə katalizatorun tarkibindən asılıdır. Müəyyən olunmuşdur ki, tadqiq olunmuş mis tarkibli katalizatorlar üzərindo sirka aldehidinin vo asetonun çıxımlarının katalizatorların torkibindən asılılıq ayrilari iki maksimumdan ibarətdir, buda çox güman binar mis tərkibli katalizatorların faza tərkibinin dəyişməsi ila alaqədardır. Müəyyən olunmuşdur ki, etanolun serium mis katalizatorları üzərində çevrilmə reaksiyasında etilasetatın əmələ galməsi kristallik dərəcəsi aşağı olan nümunələr üzarinda baş verir, asetaldehidin amala galmasi isa orta kristallik daracali nümunalar üzarində baş verir. Müəyyən olunmuşdur ki, binar mis volfram katalizatorlarının kristalliklik dəracəsinin artmasl etanolun parsial oksidloşmə məhsullarının çıxımının artmasına vo karbon qazının çıxımının azalmasına gatirib çıxarır.

Açar sözlər: etanolun çevrilməsi, binar katalizatorlar, mis oksid, sirka aldehidi, aseton, etil asetat 


\section{ПРЕВРАЩЕНИЕ ЭТАНОЛА НА БИНАРНЫХ МЕДЬСОДЕРЖАЩИХ КАТАЛИЗАТОРАХ}

\section{С.Г. Мамедова, К.Х. Агаева}

Азербайджанский государственный университет нефти и промышленности AZ-1010, Баку, пр.Азадльг, 20; e-mail: salimaabbaszade@mail.ru

Изучена реакиия превращения этанола на бинарных медь-иерий и медь-вольфрам оксидных катализаторах. Установлено, что кривые зависимости выходов уксусного альдегида $и$ ацетона от состава медьсодержащих катализаторов имеют два максимума, что, повидимому, обусловлено изменением фазового состава бинарньх медьсодержащих катализаторов. Установлено, что в реакции превращения этанола на медь-иерий оксидных катализаторах образование этилачетата протекает на слабо кристаллических образцах, а образование ацетальдегида на среднекристаллических образиах. Найдено, что увеличение степени кристалличности бинарных медь-вольфрам оксидных катализаторов приводит к увеличению выходов продуктов парчиального окисления этанола и снижению выхода углекислого газа.

Ключевые слова: превращение этанола, бинарные катализаторы, оксид меди, уксусный альдегид, ацетон, этилацетат. 